\title{
Anti-Leptospira spp. Antibodies in Pigs Slaughtered in the Agreste Region of Pernambuco, Brazil
}

\author{
Erika Fernanda Torres Samico-Fernandes, Pedro Paulo Feitosa de Albuquerque, \\ Marcela Fernanda Torres Samico-Fernandes, André de Souza Santos, Amanda Thaís Ferreira Silva, \\ Cynthia Maria Morais de Queiroz Galvão, Maria Betânia de Queiroz Rolim \& Rinaldo Aparecido Mota
}

\begin{abstract}
Background: Swine production and productivity rates can be influenced by several factors, such as genetics, environmental conditions, nutritional factors, previous infections and others. Among infectious diseases, leptospirosis is a well-known cause of reproductive disorders in pigs. These animals are considered carriers of the disease when they are in the terminal stage of the infection and the Veterinary Inspection Service has not been notified when they are slaughtered. Considering the lack of epidemiological information on Leptospira infection in pigs in the state of Pernambuco, the aim of this study was to investigate anti-Leptospira antibodies in pigs slaughtered in the Agreste region of the state of Pernambuco, Brazil. Materials, Methods \& Results: Blood samples were collected from 305 pigs in 11 municipalities in the Agreste region of Pernambuco. The animals had no history of vaccination, and were raised on subsistence-oriented family farms. The sera were subjected to the Microscopic Agglutination Test (MAT) for the detection of antibodies. The serovars used in the MAT were: Icterohaemorrhagiae, Copenhageni, Javanica, Canicola, Castellonis, Pyrogenenes, Cynopteri, Autumnalis, Sentot, Djasiman, Australis, Pomona, Grippotyphosa, Hebdomadis, Wolffi, Sejroe, Saxkoebing, Bataviae, Tarassovi, Panama, Patoc, Andamana, Celledoni, Shermani, Brastilava and Hardjo. Sera showing titers of $\geq 100$ were considered positive. The MAT results indicated that 78/305 (25.57\%) of the samples were positive, and were distributed in the 11 municipalities. The most frequent serovars were Icterohaemorrhagiae, Copenhageni, and Djasiman, with frequencies of 55.13\%, $17.95 \%$ and $6.41 \%$, respectively.

Discussion: Swine infected with leptospirosis showed few or no signs of the disease. However, the bacteria can be carried for long periods in convoluted tubules of the kidney and their urinary excretion may last for years. A study of Leptospira spp. risk factors on pig farms in the state of Alagoas revealed an absence of rodent control, suggesting that this was the probable cause of infection by this serovar, Icterohaemorrhagiae. Farms that did not control their rodent populations showed a 7.8-fold higher risk of infection among their swine. This exposure poses a problem, since these animals can contaminate the environment, as well as food and water, making them an important source of infection of other animals. The findings of this study indicate that the pigs were exposed to Leptospira spp. The reason that some atypical serovars were identified in this study may be have been incidental infection, since these animals came from a non-technified system, putting them at greater risk of contact with other animal species. This may also be a reason for the identification of the other serovars in this research. Although the serovar Copenhagen is part of the Icterohaemorrhagiae serogroup, few studies have described its importance. The main reservoirs of Copenhageni are also synanthropic rodents, which underscores the importance of these animals as possible sources of contamination on farms that supply pigs to the slaughterhouses of the region under study. The data obtained here indicate the need for animal health surveillance programs in the region. Moreover, they may also be a source of infection of the professionals directly involved in handling and slaughtering pigs. This indicates the need to implement surveillance programs in the region, such as high vaccination coverage at pig farms, as well as integrated pest management against rodents.
\end{abstract}

Keywords: leptospirosis, slaughterhouse, swine, serology. 


\section{INTRODUCTION}

Swine production and productivity rates can be influenced by several factors, such as genetics, environmental conditions, nutritional factors, previous infections and others [2]. Among infectious diseases, leptospirosis plays a prominent role in reproductive disorders, fever, birth of weak piglets, jaundice, hemoglobinuria, neurological and gastrointestinal disorders [20].

Leptospira spp. can cause lesions in various organs, but are mostly found in the kidneys, where they multiply. They are then eliminated through the urinary tract, contaminating the environment and posing a serious problem on pig farms.

Leptospirosis has been recognized worldwide as a cause of reproductive disorders in pigs [11,23], and these animals are considered carriers when they are in the terminal stage of the infection and the disease has not been notified to the Veterinary Inspection Service at the time they are slaughtered [7].

In Brazil, serological tests for the detection of anti-Leptospira antibodies have revealed seroreactivity rates of $66.67 \%$ [6], 14.58\% [13], 33.60\% [1]. Isolation of the agent has also been described [25].

Considering the lack of epidemiological information on Leptospira infection in pigs in the state of Pernambuco, this study involved an investigation into the occurrence of anti-Leptospira spp. antibodies in animals slaughtered in the Agreste region of the state of Pernambuco, Brazil.

\section{MATERIALS AND METHODS}

\section{Blood sampling}

Blood samples were collected from 305 male and female pigs in 11 municipalities in the Agreste region of Pernambuco. The animals had no history of vaccination, and were raised on subsistence-oriented family farms.

The sample size was determined considering an expected prevalence rate of $33.60 \%$ of Leptospira spp. infection [1], with a $95 \%$ confidence level and standard error of 5\% [27].

Blood samples were drawn into sterile screw cap test tubes $\left(\text { Globe }{ }^{\circledR}\right)^{1}$ immediately upon bleeding in the slaughter process. The blood samples were identified, the sera were extracted and placed in (Eppendorf ()$^{2}$ tubes. The tubes were refrigerated and sent to the Department of Bacteriology of the National Net- work of Agricultural Laboratories (LANAGRO) of the Ministry of Agriculture, Livestock and Food Supply.

Detection of anti-Leptospira spp. antibodies

The MAT test was carried out to detect antiLeptospira spp. antibodies, as recommended by Brazil's Ministry of Health [18]. The serovars used in the MAT were: Icterohaemorrhagiae, Copenhageni, Javanica, Canicola, Castellonis, Pyrogenenes, Cynopteri, Autumnalis, Sentot, Djasiman, Australis, Pomona, Grippotyphosa, Hebdomadis, Wolffi, Sejroe, Saxkoebing, Bataviae, Tarassovi, Panama, Patoc, Andamana, Celledoni, Shermani, Brastilava and Hardjo.

After initial serum dilution of 1:100, the plates were incubated and examined under dark field microscopy. Results were considered positive when agglutination reached or exceeded $50 \%$.

\section{Data and tatistical analysis}

Absolute and relative frequencies were dispersed using data analysis [24]. Statistical significance was attributed to the differences observed in the frequencies of serum-reactive animals based on Pearson's chi-square $\left(\chi^{2}\right)$ test, or Fisher's exact test, when necessary [29]. The standard error was 5\%.

\section{RESULTS}

In this pioneering study, positive seroreactivity to Leptospira spp. was detected in 78/305 (25.57\%) of blood samples collected from swine at slaughterhouses in Pernambuco.

The frequency of positive animals, divided by sex, was 38/305 (12.45\%) among females and 40/305 $(13.11 \%)$ among males. The variables of sex and age were not statistically significant in terms of seroreactivity rates.

Table 1 lists, which lists the distribution of serovars by municipality, indicates that Icterohaemorrhagiae was the serovar most frequently detected, i.e., $55.13 \%$.

\section{DISCUSSION}

Findings similar to those of this study have been reported in different locations in Brazil. In the states of Paraná, Alagoas and Minas Gerais, frequencies of antibodies to the serovar Icterohaemorrhagiae of $98.16 \%$ [6], $65.71 \%$ [13], 67.10\% [21], and $41.80 \%$ [28] have been reported in slaughtered pigs, and among breeding sows at technified swine farms. 


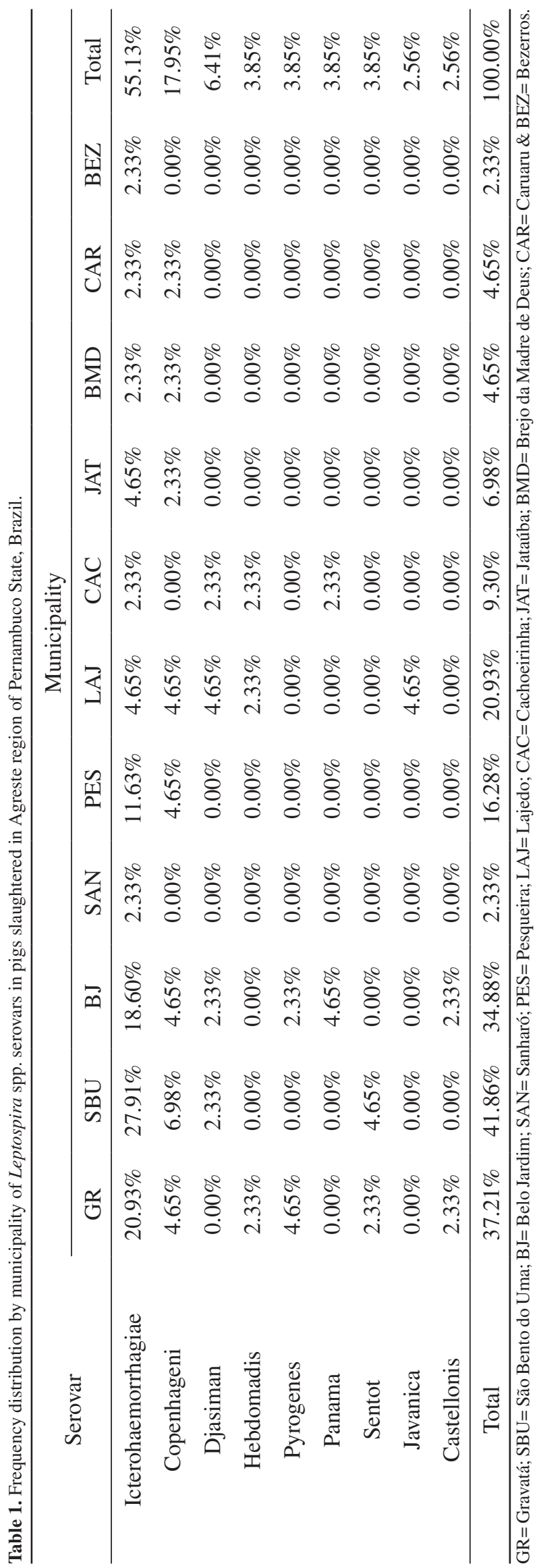

The main source of infection at pig farms that supply swine to slaughterhouses in Pernambuco are synanthropic rodents. Swine are infected by animal urine, contaminated environments and food. In this context, rats (Rattus norvegicus) are very important in the chain of infection and are also the main reservoir of the serovar Icterohaemorrhagiae [25]

A study of Leptospira spp. risk factors on pig farms in the state of Alagoas revealed an absence of rodent control, suggesting that this was the probable cause of infection by this serovar [28]. Farms that did not control their rodent populations showed a 7.8-fold higher risk of infection among their swine [3].

The most frequent serovars in pigs are Pomona, Tarassovi, Icterohaemorrhagiae, Canicola, Bratislava and Gryppotyphosa [26]. The distribution of these serovars differs among countries and even among regions in the same country $[8,17,19,22]$.

Although Pomona, Bratislava and Tarassovi serovars are considered adapted to swine [1,10], no serological evidence of these serovars was found in this study. Pomona has been identified in studies in Brazil [9,15,20], and is considered the most important serovar on Australian pig farms [4,5]. The same holds true for the serovar Bratislava, which has also been reported in Brazil [16].

The reason that some atypical serovars were identified in this study may be have been incidental infection, since these animals came from a nontechnified system, putting them at greater risk of contact with other animal species. This may also be a reason for the identification of the other serovars in this research.

Although the serovar Copenhagen is part of the Icterohaemorrhagiae serogroup, few studies have described its importance [3]. The main reservoirs of Copenhageni are also synanthropic rodents [14], which underscores the importance of these animals as possible sources of contamination on farms that supply pigs to the slaughterhouses of the region under study.

Infected pigs usually show few or no signs of the disease, but their renal system can maintain bacteria for long periods of time, eliminating them intermittently through their urine [12]. This poses a serious problem for pig farms, because these animals can contaminate the environment, food and water, and are an important source of infection for other livestock. 


\section{CONCLUSIONS}

This investigation concluded that swine slaughtered in the region under study were exposed to Leptospira spp., suggesting poor local animal health management. The results of this study indicated that the most frequent serogroup in the region was Icterohaemorrhagiae. These findings raise public health concerns, given the potential role of synanthropic rodents as reservoirs and disseminators of the pathogen, mostly of the serogroup Icterohaemorrhagiae. Moreover, they may also be a source of infection of the professionals directly involved in handling and slaughtering pigs. This indicates the need to implement surveillance pro- grams in the region, such as high vaccination coverage at pig farms, as well as integrated pest management against rodents.

\section{MANUFACTURERS}

${ }^{1}$ Globe Scientific Inc. Mahwah, NJ, USA.

${ }^{2}$ Eppendorf. Hamburg, Germany.

Acknowledgements. Special thanks to the Department of Bacteriology, National Network of Agricultural Laboratories (LANAGRO), Ministry of Agriculture, Livestock and Food Supply, for performing the Microscopic Agglutination Test (MAT).

Declaration of interest. The authors report no conflicts of interest. The authors alone are responsible for the content and writing of this manuscript.

\section{REFERENCES}

1 Azevedo S.S., Oliveira R.M., Alves C.J., Assis D.M., Aquino S.F., Farias A.E.M., Assis D.M., Lucena T.C.C., Batista C.S.A., Castro V. \& Genovez M.E. 2008. Prevalence of anti-Leptospira spp. antibodies in swine slaughtered in the public slaughterhouse of Patos City, Paraíba State, Northeast Region of Brazil. Arquivos do Instituto Biológico. 75(4): 517-520.

2 Bortoletto C., Ferreira G.F., Gasser B., Nakamura A.M., Almeida H.M.S. \& Oliveira L.O. 2014. Principais causas de problemas reprodutivos em porcas. Revista Científica de Medicina Veterinária. XII(23): revista semestral, 22p.

3 Boqvist S., Ho T.V.T., Vagsholme I. \& Magnusson U. 2002. The impact of Leptospira seropositivity on reproductive performance in sows in southern Vietnam. Theriogenology. 58: 1327-1335.

4 Chappel R.J., Ellis W.A., Adler B., Amon L., Millar B.D., Zhu S.S. \& Prime R.W. 1992. Serological evidence for the presence of Leptospira interrogans serovar Bratislava in Australian pigs. Australian Veterinary Journal. 69(5): 119-120.

5 Chappel R.J., Prime R.W., Millar B.D., Jones R.T., Cutler R.S. \& Adler B. 1998. Prevalence and geographic origin of pigs with serological evidence of infection with Leptospira interrogans serovar pomona slaughtered in abattoir in Victoria. Veterinary Microbiology. 62(3): 235-242.

6 Delbem A.C.B., Freire R.L., Silva C.A., Müller E.E., Dias R.A., Neto J.S.F. \& Freitas J.C. 2004. Fatores de risco associados à soropositividade para leptospirose em matrizes suínas. Ciência Rural. 34(3): 847-852.

7 Ellis W.A. 1999. Leptospirosis. In: Straw B.E., D’Allaire S., Mengeling W.L. \& Taylor D.J. (Eds). Disease of Swine. 8th edn. Ames: Iowa State University Press, pp.483-493.

8 Faine S., Adler B., Bolin C. \& Perolat P. 1999. Leptospira and leptospirosis. Melbourne: Medical Science, 353p.

9 Faria J.E., Ribeiro M.F.B., Santos J.L., Patarroyo Salcedo J.H. \& Dale R. 1989. Frequência de aglutininas antiLeptospiras em soros sanguíneos de suínos das microrregiões de Viçosa e Ponte Nova/MG. Arquivo Brasileiro de Medicina Veterinária e Zootecnia. 41(5): 381-388.

10 Favero A.C.M., Pinheiro S.R., Vasconcellos S A., Morais Z.M., Ferreira F. \& Ferreira Neto J.S. 2002. Sorovares de Leptospiras predominantes em exames sorológicos de bubalinos, ovinos, caprinos, equinos, suínos e cães de diversos estados brasileiros. Ciência Rural. 32(4): 613-619.

11 Figueiredo Í.L., Alves C.J., Silva L.C.A., Oliveira R.M. \& Azevedo S.S. 2013. Leptospirose suína: uma importante causa de falhas e perdas reprodutivas. Revista Brasileira de Reprodução Animal. 37(4): 344-353

12 Gonçalves D.D., Teles P.S., Reis C.R., Lopes F.M. R., Freire R.C., Navarro I.T., Alves L.A., Müller E.E. \& Freitas J.C. 2006. Seroepidemiology and occupational and environmental variables for leptospirosis, brucellosis and toxoplasmosis in slaughterhouse workers in Paraná state Brazil. Revista do Instituto de Medicina Tropical de São Paulo. 48: 135-140.

13 Hashimoto V.Y, Anzai E.K., Lima B.A. C., Silva F.G., Alves L.A., Freire R.L., Teles P.S., Garcia J.L., Müller E.E. \& Freitas J.C. 2008. Associação entre as lesões renais microscópicas e a presença de anticorpos contra Leptospira spp. em suínos aparentemente sadios, abatidos em frigorífico da Região Norte do Estado do Paraná. Semina: Ciências Agrárias. 29(4): 875-880. 
14 Heath S.E. \& Johnson R. 1994. Leptospirosis. Journal of the American Veterinary Medical Association. 205(11): 1518-1523.

15 Larsson C.E., Yasuda P.H., Santa Rosa C.A. \& Costa N.O. 1984. Lepstopirose suína: inquérito sorológico e bacteriológico em municípios dos estados de São Paulo, do Paraná e de Santa Catarina. Revista da Faculdade de Medicina Veterinária e Zootecnia da Universidade de São Paulo. 21(1): 43-50.

16 Lima P.C.R. 1996. Diagnóstico de leptospirose em suínos no Rio Grande do Sul: exames laboratoriais em fêmeas suínas descartadas em frigoríficos e em reprodutores de granjas com e sem problemas de reprodução, durante o período de um ano. Arquivos da Faculdade de Veterinária da Universidade Federal do Rio Grande do Sul. 24(1): 119-121.

17 Michna S.W. \& Campbell R.S.F. 1969. Leptospirosis in pigs: epidemiology, microbiology and pathology. The Veterinary Record. 84(6): 135-138.

18 Ministério da Saúde. 1995. Manual de Leptospirose. 2.ed. Brasília: Fundação Nacional de Saúde, 98p.

19 Modolo J.R., Langoni H., Gottschalk A.F., Stachissini A.V.M. \& Berto D.A. 2000. Seroprevalence of Leptospira interrogans serovar djasiman in quarantined pigs. Indian Veterinary Journal. 77(2): 155-156.

20 Oliveira S.J., Bortolanza F., Passos D.T., Simões Pires-Neto J.A., Fallavena L.C.B. \& Weimer T.A. 2007. Molecular diagnosis of Leptospira spp. in culled sows. Brazilian Journal of Veterinary Research and Animal Science. 44(1): $18-23$.

21 Osava C.F., Salaberry S.R.S., Nascimento C.C.N., Lima-Ribeiro A.M.C., Moreira R.Q., Castro J.R. \& Rigo V.H. 2010. Ocorrência de anticorpos anti-Leptospira spp. em diferentes sistemas de criação de suínos. Bioscience Journal. 26(2): 202-207.

22 Pereira J.A. 2009. Soroprevalência da Infecção por Leptospira spp. em matrizes suínas oriundas do Médio Norte do Estado de Mato Grosso, Brasil. 67f. Cuiabá, MT. Dissertação (Mestrado em Ciências Veterinárias) - Faculdade de Agronomia, Medicina Veterinária e Zootecnia, Universidade Federal de Mato Grosso.

23 Ramos A.C.F., Souza B.G.N. \& Lilenbaum W. 2006. Influence of leptospirosis on reproductive performance of sows in Brazil. Theriogenology. 66: 1021-1025.

24 Sampaio I.B.M. 2003. Estatística Aplicada à Experimentação Animal. Belo Horizonte: FEPMVZ, 221p.

25 Shimabucuro F.H., Dominues P.F. \& Langoni H. 2003. Pesquisa de suínos portadores renais de leptospiras pelo isolamento microbiano e reação em cadeia pela polimerase em amostras de rins de animais sorologicamente positivos e negativos para leptospirose. Brazilian Journal of Veterinary Research and Animal Science. 40(4): 243-253.

26 Sobestiansky J., Barcellos D., Mores N., Carvalho L.F. \& Oliveira S. 1999. Clínica e Patologia Suína. 2.ed. Goiânia: Universidade Federal de Goiás, 464 p.

27 Thrusfield M.V. 2004. Epidemiologia Veterinária. 2.ed. São Paulo: Roca. 556p.

28 Valença R.M.B., Mota R.A., Castro V., Anderlini G.A., Pinheiro Júnior J.W., Brandespim D.F., Valença S.R.F.A. \& Guerra M.M.P. 2013. Prevalence and risk factors associated with Leptospira spp. infection in technified swine farms in the State of Alagoas, Brazil. Transboundary Emerging Diseases. 60(1): 79-86.

29 Zar J.H. 1999. Biostatistical Analysis. 4th edn. Upper Saddle River: Prentice-Hall Inc., 663p 